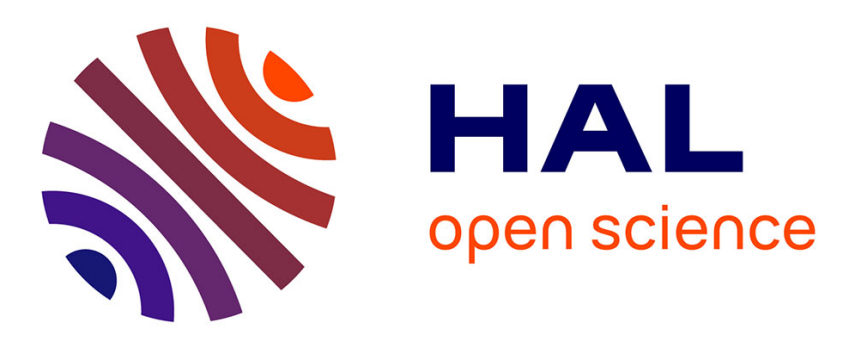

\title{
Green Path Development and Green Regional Restructuring for Sustainable Development
}

\author{
Most Asikha Aktar, Mukaramah Binti, Md Mahmudul Alam
}

\section{To cite this version:}

Most Asikha Aktar, Mukaramah Binti, Md Mahmudul Alam. Green Path Development and Green Regional Restructuring for Sustainable Development. Industry, Innovation and Infrastructure, Springer International Publishing, pp.1-12, 2021, Encyclopedia of the UN Sustainable Development Goals, 10.1007/978-3-319-71059-4_123-1. hal-03520061

\section{HAL Id: hal-03520061 \\ https://hal.science/hal-03520061}

Submitted on 10 Jan 2022

HAL is a multi-disciplinary open access archive for the deposit and dissemination of scientific research documents, whether they are published or not. The documents may come from teaching and research institutions in France or abroad, or from public or private research centers.
L'archive ouverte pluridisciplinaire HAL, est destinée au dépôt et à la diffusion de documents scientifiques de niveau recherche, publiés ou non, émanant des établissements d'enseignement et de recherche français ou étrangers, des laboratoires publics ou privés. 


\title{
Green Path Development and Green Regional Restructuring for Sustainable Development
}

\author{
Most. Asikha Aktar \\ Assistant Professor, Department of Economics \\ Cumilla University, Cumilla, Bangladesh \\ Email: asikharita@gmail.com \\ Mukaramah Binti Harun \\ Associate Professor, School of Economics, Finance \& Banking \\ Universiti Utara Malaysia, Sintok, Kedah, Malaysia \\ Email:mukaramah@uum.edu.my \\ Md. Mahmudul Alam \\ Senior Lecturer, School of Economics, Finance \& Banking \\ Universiti Utara Malaysia, Sintok, Kedah, Malaysia \\ Email: rony000@gmail.com \\ *Corresponding Author
}

\section{Citation Reference:}

Aktar M.A., Ahmed, U.A., \& Alam M.M. (2020). Green Path Development and Green Regional Restructuring to Sustainable Development. In: Walter Leal Filho et al. (eds), Industry, Innovation and Infrastructure: Encyclopedia of the UN Sustainable Development Goals. Springer, Cham. ISBN: 978-3-319-71059-4. (Online) https://doi.org/10.1007/978-3-31971059-4_123-1

This is a pre-publication copy.

The published article is copyrighted by the publisher. 


\section{Green Path Development and Green Regional Restructuring for Sustainable Development}

\section{Definition}

The concept of green energy has come to the fore as a strategic sustainable energy formation process for the whole world since last three decades, but it has gained enormous interest during recent years. Green Energy is referred to clean sources of energy that generates lower environmental impact in relation to conventional energy technology (Bhowmik et al. 2017). In terms of reducing negative environmental impact, highlighting the importance of Green Energy on environment, sustainability researchers have increasingly utilized this lens to explain the multi-dimensions of many sustainable development issues, and explored new ways for addressing the most recent concept. In addition, for defining various aspects of sustainability, Green Energy concept is not a new concept rather it is an emerging concept.

\section{Introduction}

Energy is required for every society with a view to meeting the basic needs, so the insecurity of its supply can creep-up the work of a nation's economy. In this regard, transition towards green energy has come to be known as a "premeditated product". In this section, the transition toward green energy, green energy in the perspective of sustainable development and its four distinguishing contribution are discussed. These contributions are then used to discuss the sustainable development dimensions, which are stated in the literature review.

Now-a-days, two issues regarding energy are drawing attention to the sustainability researchers. One is how to assure energy supplies in a sustainable manner which has low environmental impacts and low emissions capacity, and the other one is barriers to sustainable energy development and identifying the most efficient way of addressing such barriers. An outline is provided for reconstructing the agenda of sustainable development in such a way that the issues of agenda must be consistent with the goals and values of sustainability. As researchers and practitioners have struggled with the issue of energy sustainability, recognition has emerged out of the fact that if they are taken positively, they will lead to a sustainable economic and social development; the entry ends with conclusion.

\section{Transition toward Sustainable Green Energy}

Maintaining higher and sustainable development is the prime area for the Government strategies throughout the world. This activity requires large amount of substantial and energy inputs are essential for attaining sustainability. Nevertheless, the abundant use of such natural resources has induced serious environmental problems and imposed negative consequences on the human health as well as on productivity by increasing the concentration of greenhouse gasses (GHG) in the air, as they generate huge waste by-products in the process of attaining greater economic activities.

Accordingly, these activities also lead to increase the sea level, air temperature, global ocean, and melting of snow and ice sheets as well as exhaustion of the different species throughout the world. These are collectively called as the effect of the global warming and climate change caused by rising the concentration ratio of GHG in the environment. According to Bernstein et al. (2007) and Lau et al. (2010), by 2100, the existence of half of the world's populace, particularly people who are living in the coastal area might be in danger because of increasing global temperature on an average to $6.4^{\circ} \mathrm{C}$ from $1.1^{\circ} \mathrm{C}$ and rising the sea level by about 16.5 to $53.8 \mathrm{~cm}$ respectively.

"Global Climate Change" which is an alarming problem for attaining sustainable development in these days. Although the impact of global climate change is definite on human health and environment, therefore, it is difficult to predict the change and many people start realizing that 
unpredictable change of global climate is a key barrier for attaining sustainable development, while more than half of the global climate change is caused by the increasing concentrations of GHG emissions and contributed mainly by the energy sector (Climate Group, 2009).

As a larger contributor, energy sector stands for roughly two-thirds of all GHG emissions (IEA 2015). In addition, over the decades, Carbon Dioxide emissions $\left(\mathrm{CO}_{2}\right)$ which is known as the foremost creator of GHG from the energy sector have risen at a higher levels that account for about 55 percent of total GHG emissions (IEA, 2015).

As a result, energy-related carbon Dioxide $\left(\mathrm{CO}_{2}\right)$ has received more consideration everywhere in the world as the most extensive pollutant. According to Wen-Cheng Lu (2017), about 52 percent of annual energy-related $\mathrm{CO}_{2}$ hails from developing nations and it has been anticipated that, in future, a large volume of energy-related $\mathrm{CO}_{2}$ will be released from there even though now two-thirds of total $\mathrm{CO}_{2}$ come from developed countries that consume energy five times more than the developing countries. Because of higher economic progression and development of the international market, energy consumption will be heightened by developing nations and it increases by about 90 percent of the total expected increase in consumption of global energy. To be precise, activities related to power generation, deforestation, and transportation, industrial, residential and commercial are the indication of human activities that are strictly correlated to the $\mathrm{CO}_{2}$ emission. In general, $\mathrm{CO}_{2}$ is discharged into the atmosphere from combustion of non-renewable fuels, such as oil, coal and natural gas as sources of energy. The International Panel on Climate Change (IPCC) in such circumstance have specified that, if there is no proper commitment and urgent action is not taken to control the use of fossil fuel coal energy, the $\mathrm{CO}_{2}$ emission will be released in the atmosphere at an unprecedented rate (IEA, 2015). Consequently, the degree of global climate change will be overstated leading to strong long-term effects around the world, which is already escalating at the present time.

Moreover, it is an undeniable fact that, the number of nations for sustaining their economic progress still now extensively reliant on fossil fuels energy sources. For this reliance on fossils fuels energy which is not green generates extensive $\mathrm{CO}_{2}$ emission, global warming and overwhelming environmental problems, like storms, floods, and droughts etc. as regular phenomena throughout the world. It has been estimated that for the period of $20^{\text {th }}$ century, roughly thirty billion tons of $\mathrm{CO}_{2}$ from the burning of fossil fuels move into the atmosphere each year, while for the past few years fossil fuels burning of $\mathrm{CO}_{2}$ emission also has showed an increasing trend (IEA, 2015). Furthermore, 80 percent more of total future primary energy demand will be met by non-renewable fossil fuels energy sources, therefore accounts for about more than $90 \%$ of total energy- related $\mathrm{CO}_{2}$ emissions.

Currently, the high growth of energy demand which has been accompanied with the long term economic growth and development of global market leads to increase the dependency on nonrenewable fossils fuels energy, and it has resulted in $\mathrm{CO}_{2}$ emission Therefore, a strong correlation between economic growth and energy demand is reflected as an emissions driver in the environment (Stern, 2011). As such, global energy demand increases to $2.1 \%$ along with global economic growth at a rate of $3.7 \%$ in 2017 . While, the share of fossil fuels to global energy demand increased by $81 \%$ as a whole. Consequently, global $\mathrm{CO}_{2}$ emissions from energy grew by about $1.4 \%$ which was equivalent to an increase of 460 million tonnes (Mt) (IEA, 2018).

However, such growth of energy-related $\mathrm{CO}_{2}$ emission is an advance and dire warning toward global efforts of combating climate change and demonstrates that the current effort is not sufficient to meet the Paris Agreement goals (global average temperature is no more than $2^{0} \mathrm{C}$ ). According to Roberts, (2017) there exists gap between the goals of Paris climate change (below $2 \%$ ) and actuality (above 4\%). Number of scholars predicted that, without taking exact course of actions all hope of attaining two degrees will almost certainly be out of reach as well, and the world environment will face the challenges of sustainability. In addition, we will reach a 
level that will not be bearable anymore. Accordingly, it is urgently needed to adopt the right policies for developing green energy strategies for sustainable future that will limit warming close to 2 degree by generating low to zero emissions, and this calls for immediate action by all nations.

Consequently, recent years have received considerable attention by scientists and policy makers due to their growing concern for green energy strategies on the way to sustainable development. Therefore, Green Energy, which is generally originated from natural sources, like sunlight, wind, rain, tides, plants, algae, geothermal heat those are naturally renewable as well as environmentally friendly and more sustainable (Bhowmik et al. 2017). In the process of transition towards green energy set of opportunities can produce enormous benefits for the world by the way of sustaining economic and social development, insuring access to energy for all, enhancing security of energy, improving the quality of environment by reducing the reliance on fossil fuels and mitigating climate change with cutbacks of greenhouse gasses and overall emissions from the industrial and non-industrial sectors.

Noticeably, one of the key objectives of sustainable development is to secure the supply of energy resources for all generations, and that must be least costly and release minimal emission (Sen and Ganguly 2017). Therefore, green energy have met the objectives of sustainability i.e., which are least costly, efficient means for improving the sustainability of a country's productive sector, people's standard of living and environment (Yushchenko \& Patel 2016). On the other hand, fossil fuels as energy resources are limited and have lack of attributes which are required for meeting the objectives of sustainability. By considering the benefits of green energy over fossil fuels energy, Midilli et al. (2004a, b) stated that long-standing and proactive policies should be applied at a greater extent to surge the practice of green energy around the world, which is considered as a key element of the interaction between nature and society.

\section{Green Energy in the Context of Sustainable Development}

Though the term Sustainable Development is difficult to define, as a concept, it is very popular throughout the world. There exist number of agreements of defining the term sustainable development i.e. what is it, how it is different from the term sustainability and how it can be achieved. In view of that, this term has more than one definitions and hypothetical justifications by the policy makers in spite of the strong conceptual background.

However, one of the most widely held definitions is provided by the Brundtland report in 1987; defined as "sustainable development is development that meets the needs of the present without compromising the ability of future generations to meet their own needs". Another often-quoted definition by Caring provides for the Earth: "improving the quality of human life while living within the carrying capacity of supporting ecosystems" (Munro 1995).

In general, it is a key approach of achieving social, economic and environmental issues simultaneously (Dincer and Rosen 2005). To come out of the concept of sustainable development in front of the world, agenda 21 as a basic framework was suggested by the United Nations World Commission on Environment and Development in 1992 in Rio de Janeiro, and United Nations World Commission was a pivotal driver for the United Nations Conference on Environment and Development (UNCED).

A number of new and emerging issues were outlined there, and the importance of energy as an essential factor of sustainable development was also discussed. However, energy for sustainable development achieved priority in the year 2000 when economic growth faced the challenges of sustainability and was recognized as an aspects of sustainability in 2002 at the World Summit for Sustainable Development (WSSD). Therefore, the scholar stated that sustainable development is the union of energy and resources sustainability as well as economic, environmental, and social sustainability (Dincer and Rosen 2005). As illustrated in 
figure-1, the key drivers of achieving sustainable development and also the interaction among them.

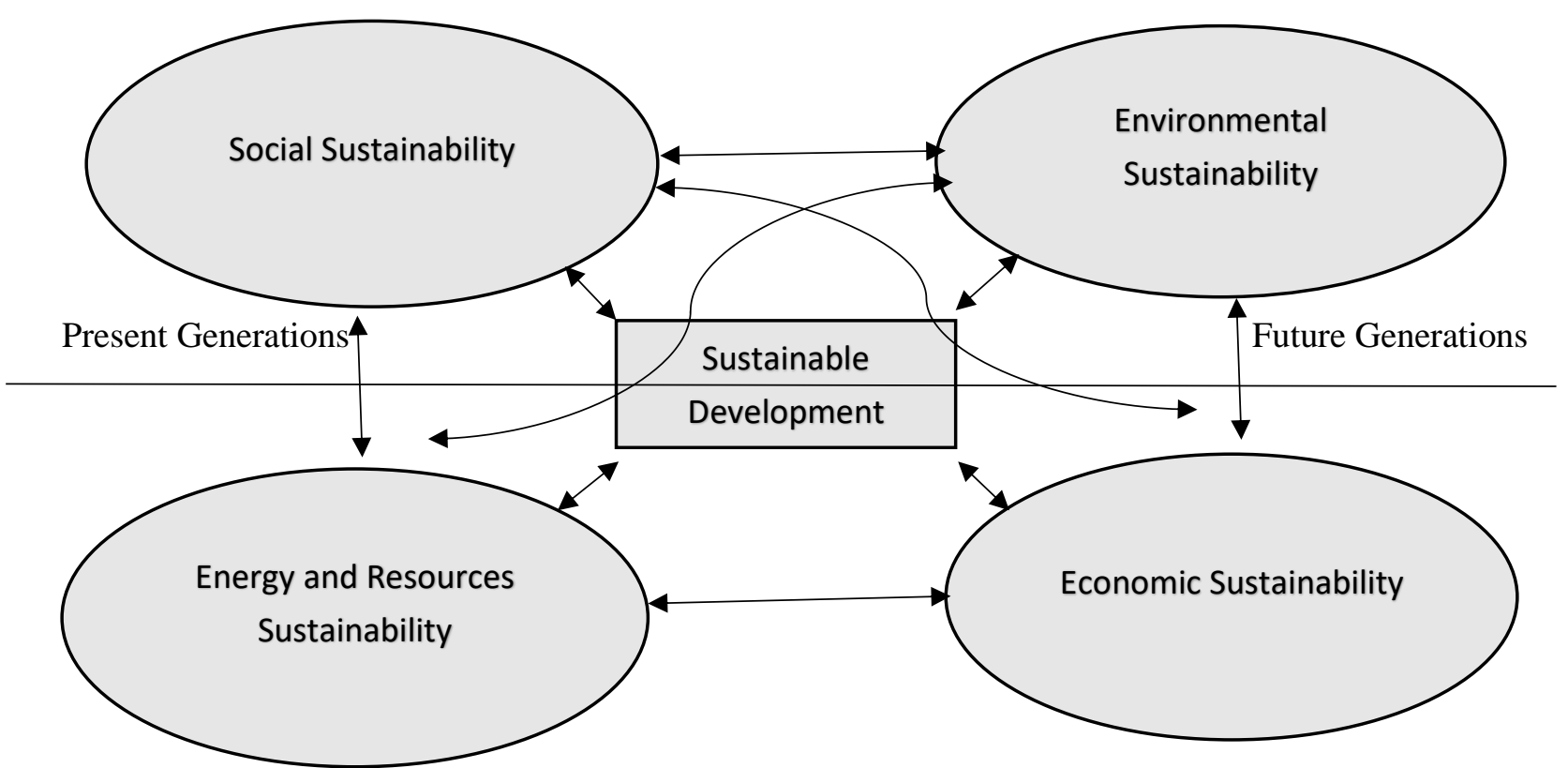

Fig. 1. Factors affecting sustainable development and their interdependence (adapted from Dincer and Rosen, 2005).

Amongst different categories of energy, the green energy have received greater importance and attentions in the context of sustainability. Due to the competency of lowering the level of emissions as well as of minimizing the undesirable effects on environment, green energy has been acknowledged as the nuts and bolts of attaining the goals of sustainable development (Bekhet \& Harun 2017; Dogan \& Seker 2016). Instantly, the impacts of global financial crisis and climate change has risen worldwide concerns to reorganize the economy structure by shifting towards a path that will secure environmental sustainability by lowering the negative impacts on environment and society; originating the term 'Green Energy' (Mundaca et al. 2016).

Globally it has been agreed that, the practice of Green Energy should be increased at a larger scale for maintaining the energy sectors sustainability and that is true not only for developed countries but also for developing and emerging countries. Dincer and Rosen (2005) highlighted three main reasons for practicing green energy as a key tool of sustainable development, and those are following:

1. Compared to conventional energy sources, Green energy sources produce lower knock-on effect on environment.

2. By nature, Green Energy is not exhausted. It can supply cleaner and greener energy indefinitely at a sustainable manner compared to other sources of energy.

3. Small scale equipment and less time are required for the production of green energy. At the local level, who have less access to energy consumption can be facilitated by the green energy sources that provide opportunities for decentralization and local solutions that are more or less free from the national network. Thus, the production of green energy boosts the flexibility and economic benefits for the local people by delivering compliance in case of erratic economic growth and unstable energy demand.

\section{Contributions of green energy to sustainable development}


Although Green Energy is a key tool for attaining sustainable development, desired outcome would not be possible if efficient policy is not designed to protect the environment and consider the economic and social matters instantaneously. Precisely, Green Energy is crucial for sustainable development, because it has the capability of reducing social, political, economic and environmental conflict globally. Therefore, planning sustainable green energy strategies is very crucial. However, the major contributions of the deployment of green energy strategies to sustainable development are provided in the following:

\section{(i) Sustainable Socio-Economic Development}

Energy sector stipulates significant contribution to economic development by fostering the significant correlation between economic growth and energy consumption. Generally, both Gross Domestic Product (GDP) and Human Development Index (HDI) are the most widely used variables for measuring the economic development of a country whereas employment variable is used to quantify the social development (Sathaye et al. 2011). Hence, to justify the role of energy for sustainable social and economic development can be described in the following manner:

Energy and Economic Growth: Literature have argued that there exists strong positive association between per capita income and per capita energy consumption (Sen and Ganguly 2017). Since the last few years, economic growth has been considered as one of the most governing factors behind the expansion of energy consumption. Hence, economic growth which is associated with greater economic activities leads to higher demand for electricity which is called the driver of automation and modernization of production as well as a main contributor to maintaining the continuity of productivity. Nevertheless, usage level of energy may vary based on the economic structure of a country (Sen and Ganguly 2017). Such as, countries which are at the initial point of development have to consume large amount of energy derived from conventional sources. In addition, the consumption of energy followed by residential sector and manufacturing sector for the emerging countries, while transportation and service sectors for the fully industrialized countries.

Energy and Human Development Index (HDI): HDI plays an important role in measuring the welfare of society (Sathaye et al. 2011). There exists a significant positive relationship between energy consumption, and HDI implies that countries with higher level of HDI consume relatively higher level of energy (UNDP 2010; World Bank 2010). Therefore, conservation of quality standard of living needs green and reliable energy. According to UNDP (2007) green energy is more reliable types of energy to improve the quality of human wellbeing i.e. education and health quality, gender equality, socio-economic status of the poor people.

Energy and Employment: In the process of transition towards green energy, job creation is one of the utmost positive outcomes for both the developed and developing countries (Sen \& Ganguly 2017). Also it has negative effects on employment because some people lose their jobs during transitional period, but the significance of positive consequence of green energy on employment outweighs the negative consequences (Frondel et al. 2010).

Currently, countries, like Japan, China, Korea, European Union and United States put more emphasize on the implementation of Green Energy because it provides opportunities of new employment creation (UNEP 2010). In addition, the study conducted by Barbier (2009) shows that a 'Global Green New Deal' might open up over 34 million jobs in the long run in some sectors, like low-emission intensive transportation and related sectors. 


\section{(ii) Increase Energy Access}

The majority of the world population have lack of access to green energy. From the viewpoint of sustainable development, extension of sustainable green energy is indispensable for those people who have lack of opportunities to access cleaner and greener energy and who are living in the rural areas and have no connections with the grid. In 2009, it has been estimated that more than 1.4 billion people of the total population in the world have no way to access to electricity, and eighty-five percent of them are from countryside (IEA, 2010).

One of the objectives of the Millennium Development Goal (MDG) is to reduce the number of world poverty by $50 \%$ within 2015 . Ensuring access to electricity and modern fuels for more than 1.2 billion and 1.9 billion people are needed in order to achieve this goal (UNDP/WHO 2009). Green energy can meet the energy demand of local rural communities at economical and sustainable ways. Since access to green energy means access to energy that is clean, affordable, and reliable. Now-a-days, substantial initiative has taken especially by the emerging countries in order to increase access to Green energy. Such as installation of solar (PV) which is the attractive form of fulfilling very basic energy needs; on the other hand, hydropower and bioenergy account for meeting greater local energy demand.

\section{(iii) Enhance Energy Security}

There is no acceptable meaning of defining the term "energy security". According to Kruyt et al. (2009), it can be defined based on context. However, the word "Energy security" can be defined as to ensure the provision of energy over the period of time without the influence of any distraction (Grubb et al. 2006). There are two far-reaching aspects of explaining the term energy security; one is the efficient allocation and readily available of energy resources, and another is reliability and variability of energy supply (Bazilian and Roques 2008).

Nowadays, countries around the world faces the challenges of ensuring sustainable supply of energy due to the strong correlation between energy consumption and economic growth. Higher energy demand associated with worldwide higher economic growth increasingly puts pressure on the existing energy resources and also expands the gap between energy supply and demand in each sectors as well as increases the tension about the inadequacy of energy supply. Another critical issue regarding higher energy demand is that the dependency on fossil fuels energy increases at an unexpected level. If current energy demand is continuously met by only fossil fuels, the existing fossil fuels reserves will be exhausted more rapidly, and that situation is not very far from now. This growing concern about the potential for the scarcity and limited availability of future energy resources of fossil fuels permits nations for a transition to a more sustainable green energy system. Green energy which is extracted from nature therefore is more reliable and available also can yield energy security by way of expanding the options of energy supply and reducing the usage of fossil fuels energy.

\section{(iv) Improving Environmental Quality \& Mitigating Climate Change}

Mitigating the impact of climate change and improve the quality of environment is the crucial factor for the emergence of increasing demand for green energy system. Recently, policymaker have come to the conclusion that if no action is taken to combat global climate change, the impact of climate change on environment will be far-reaching and overwhelming. On the other hand, conserving environment from the devastating effects of climate change is the major issues of sustainable development.

Therefore, COP 21 which was held in December 2015 in the United Nations Framework Convention on Climate Change (UNFCCC) was considered as a milestone for the increasing worldwide effort to mitigate the impact of climate change and to reduce the adverse effects of global temperature by limiting on an average $2{ }^{\circ} \mathrm{C}$ at the end of the period 2030 (UNFCC 2010). 
In the Conference, governments from around the world were requested to submit their set of targets and policy strategy in order to limit global temperature.

After reviewing each countries target and policy strategy, it has come out that the deployment of green energy is a key pillar for mitigating the impact of climate change. It has been argued that green energy strategy can help to meet the global climate goals without any effects on economic growth and welfare (Mundaca et al. 2016). In addition, green energy has significant impact of reducing air pollution and health hazards. As for example, traditional energy seriously affects health and environment by the discharge of carbon dioxide emission and other pollutions. Long term exposure of such pollution can contribute to severe health related diseases. In this case, non-combustion based green energy is able to produce very less amount of pollution compared to the fossil fuels as well as conserve the factors that affect sustainable development.

\section{Barriers to Green Energy Deployment in a Sustainable Development Context}

Explaining green energy strategy in the perspective of sustainable development include all the issues of sustainability, such as environmental, social and economic. This interdependence among the variables implies that the task to form green energy strategy is not easy because there are some barriers to green energy deployment, and those barriers are embedded in the specific social, economic, and environmental perspectives that have been described below.

\section{(i) Economic Barriers}

The assessment of the economic barriers to green energy requires explicit social costs and benefits analysis. Social benefits conclude that the lower supply of goods is associated with lower price whereas social costs conclude that since consumers do not bear the full costs, the demand for the harmful activities will increase. Therefore, economic barriers towards the deployment of green energy can come as -

- Shortage of investment for the adaptation of green energy technologies

- Underrated environmental shocks

- High investment cost, especially for developing countries.

- Uncertainty of future energy prices

- Financial risks

\section{(ii) Informational and Awareness barriers}

Informational and awareness barriers arise due to lack of in depth data on green energy sources, lack of skilled human resources, and lack of technical how-to-know, etc. As such, wind energy, which is one of the fastest growing source of cleaner and greener energy has been recognized as the most acceptable source of energy (Ucar and Balo 2009; Akdag and Guler 2010). For instance, how much energy would be generated by the wind turbine, depends on wind speed and also on other related factors. Although national scale data on wind may be available, in most of the cases, local scale area specific data on wind may not be available.

Similarly, in case of solar, there is no availability of reliable data on solar radiation. As a result, it is arduous to estimate the produced output from the solar power as well as from the return on investment. For geothermal, the problem lies in the case of proper making out of the basin. Such unavailability of data stands as the key obstacles for the development of Green energy. Moreover, successful implementation of green energy system depends on skilled human resources with specific training (Martinot 1998). Moreover, there is a lack of opportunities for training workforce that is a major barrier for the developing countries.

Although some of the developed countries have been successful on implementing green energy system, while for developing countries technical and financial aspects are considered the key barriers to implement the system. However, there is lack of technical and institutional 
knowledge regarding how the country will move from traditional energy technologies to modern environmental friendly green technologies.

\section{(iii) Socio-Cultural Barriers}

Currently, green energy as environmental-friendly energy has gained support from the general public. Socio-cultural barriers is strongly linked with general and individual values and norms. Such standards (values \& norms) play critical role in determining the society's acceptance and perception regarding the deployment of green energy technologies that have impacts on distribution of resources (GNESD 2007b; Sovacool 2009; West et al. 2010).

Socio-cultural barriers in the perspective of sustainability arise from lack of concentration on social and cultural aspects. For example, a land can be used for multiple purposes. It can be used for agricultural activities, and at the same time, that can be used for wind turbines. Nevertheless, some green energy resources hider the multiple usages of land; for example, dams for hydropower require areas which put pressure on agriculture land area and also reduce area that is used for urban development.

Another most practical example in that case is that although the deployment of mini hydropower system has brought benefits for the Papua New Guinea villagers, they have demanded the compensation for using their land in order to install that system (Johnston and Vos 2005). Thus, social acceptance plays an important role for the successful implementation of green energy system in the context of sustainable development.

\section{(iv) Market Barriers}

Successful implementation of green energy system also depends on market structure. If the market structure has the features of monopoly market, there exists institutional barriers (Besant-Jones 2006). Energy industry in a number of countries has encountered a small number of competitors. As a result, highly centralized system is developed associated with fewer participating organizations. Such system which dominates the production, distribution, and transmission process implies that it is difficult to adapt green energy system at a larger scale. Hence, a modification of market structure is required at a priority basis for the successful transition towards green energy system.

\section{Policy Strategies for a Green Sustainable Energy Future}

In future, for dealing with sustainable energy, the obligatory fact is to develop sustainable green energy strategies. Notably, to increase the adequate supply of green energy, the following strategies should be undertaken by both the developed and developing countries.

- Making stronger obligation to Green Energy

- Organizational support to Green Energy

- Institutional and technical support to green energy

- Publicizing of the importance of green energy for achieving sustainable development goals

- Enhancing National and International Collaboration

Expansion of green energy market can be accelerated by providing price signals (Sen and Ganguly 2017). Such price signals that take in externalities consist of environmental and human health related problems. Therefore, the initial task is to set the targets of green energy, and the next task is to choose the dedicated policies to implement the target that will provide strong market signal and illustrates government obligation to the green energy development. Complementary measures can also be taken to reduce subsidies on fossil fuels and pricing externalities based on country's local condition (UNEP et al. 2015). As such dedicated policy framework is able to generate sustainable investment environment that can foster the 
deployment of green energy and overcome barriers to green energy expansion in the perspective of sustainability.

Expansion of green energy largely depends on financial support that will come not only from public sector but also from private sector. To widen investment in green energy deployment, there is a need to incur sufficient fund. Even though public sector fund will remain as a promoter of green energy investment, a larger amount of new investment in green energy should be encouraged from the private sector.

The important point firstly relates the exploration of the sources of green energy from where it can be produced abundantly. Then, the second point ensures the institutional and technical support to extract green energy from those sources. For instance, some countries are wellendowed with natural sources, but still now they meet up their energy demand by the fossil fuels energy. This is due to the lack of institutional and technological assistance.

For achieving the sustainable development goals, energy is considered as foundation (Dincer 1999). Indicates that development is not possible without energy whereas sustainable development will not be possible without the deployment of environmentally sustainable modern energy services. It is discernable that, cost-effective and stable energy can help not only to meet the sustainable development goals, namely affordable and clean energy but also meet other goals of SDGs i.e. bringing welfare for the people, reducing inequalities, creating new employment opportunities, reducing poverty, sustaining cities and communities and mitigating climate change.

Furthermore, initiatives, such as Common initiatives can lower the cost of deployment of green energy worldwide and also accelerate financial and technical assistance and increase economics of scale, stimulate trade domestically and internationally (Sen and Ganguly 2017). Numerous benefits can be obtained by the country who are participating in the common initiative. They are given below.

- Deployment of Green Energy requires large scale investment that is difficult to finance for a single country. By collaborating with others, country can overcome the problems of financial deficiency.

- Acting as a joint market can make negotiations with other partner countries, reducing further the costs of deployment green energy.

- Enjoyment of the opportunities of sharing human and technological resources, which are essential factors for producing green energy from the renewable sources.

- Therefore, global collaboration could serve as an effective platform for sharing technological knowledge and the best practice for expanding green energy markets. By taking into account the benefits of global collaboration, governments of each countries should be engaged in closed collaboration with each other.

\section{Conclusions}

It is obvious that the role of Green Energy for a sustainable energy in future is inexorable. The leading component that determines the importance of green energy is energy demand. With the purpose of meeting energy demand, countries around the world have taken initiatives to produce green energy from the natural sources like hydraulic, solar power, wind, tidal wave, geothermal, biogas and biomass, etc. Countries will be able to obtain the sustainable development when green energy is abundantly produced.

The abundant supply of green energy can help the country by providing a more sustainable energy in future, enhancing the energy security for all of its populace, reducing the negative impacts on human and environment and lessening conflicts among nations regarding energy reserves. Therefore, for conserving global sustainability, it is mandatory to decrease the use of energy that is generated from the fossil fuels and substitute it by green energy. However, by 
taking into account the important role of green energy for reducing global crisis and obtaining sustainability, transition towards green energy should be encouraged.

\section{Synonyms}

Green, Sustainable, Environmental friendly

\section{Cross Reference}

Wind Energy Potential (Ucar and Balo)

Wind Energy Investment (Akdag and Guler)

\section{References}

Bazilian M, and F Roques (eds.) (2008) Analytical Methods for Energy Diversity and Security. Portfolio Optimization in the Energy Sector: A Tribute to the work of Dr. Shimon Awerbuch. Elsevier Science, Oxford, UK and Amsterdam, The Netherlands.

Bekhet HA \& Harun NH (2017) Elasticity and Causality among Electricity Generation from Renewable Energy and Its Determinants in Malaysia. International Journal of Energy Economics and Policy, 7(2), 202-216.

Bernstein L, Bosch P, Canziani O, Chen Z, Christ R, Davidson O, Yohe G (2007) Climate change 2007: Summary for policymakers. Hemisphere. 57(8), 267-269.

Besant-Jones JE (2006). Reforming power markets in developing countries: what have we learned? (pp. 1-164). Washington, DC: World Bank.

Bhowmik C, Bhowmik S, Ray A, Pandey KM (2017) optimal green energy planning for sustainable development: A review. Renew Sust Energ Rev 71:796-813.

Dincer I (1999) Environmental impacts of energy. Energy policy, 27(14), 845-854.

Dincer I and Rosen MA (2004) Exergy as a driver for achieving sustainability. International Journal of Green Energy, 1 (1), 1-19.

Dincer I and Rosen MA (2005) Thermodynamic aspects of renewables and sustainable development. Renewable and Sustainable Energy Reviews, 9, 169-189.

Dogan E and Seker F (2016) Determinants of CO2 Emissions in the European Union: The Role of Renewable and Non-Renewable Energy. Renewable Energy, 94, 429-439.

Frondel, M, Grösche P, Huchtemann D, Oberheitmann A, Peters J, Angerer G, Sartorius C, Buchholz P, Röhling S, and Wagner M (2007). Trends der Angebots- und Nachfragesituation bei mineralischen Rohstoffen. Rheinisch-Westfälisches Institut für Wirtschaftsforschung (RWI), Fraunhofer-Institut für System- und Innovationsforschung (ISI), and Bundesanstalt für Geowissenschaften und Rohstoffe (BGR), Essen, Karlsruhe, and Hannover, Germany.

GNESD (2007b) Renewable Energy Technologies and Poverty Alleviation: Overcoming Barriers and Unlocking Potentials. Global Network on Energy for Sustainable Development (GNESD), Roskilde, Denmark.

Grubb M, Butler L, Twomey P (2006). Diversity and security in UK electricity generation: The influence of low-carbon objectives. Energy policy, 34(18), pp.4050-4062.

IEA (2010) World Energy Outlook. Paris, France: International Energy Agency; 2010. p. 736.

IEA (2015) Energy and Climate Change; World Energy Outlook Special Report; IEA: Paris, France.

IEA (2015). Southeast Asia energy outlook 2015-world energy outlook special report. Accessed 13 July 2016, from https://www.iea.org/publications/freepublications/publication/weo2015_southeastasia.p df

IEA (2018) Global Energy and CO2 Status Report 2017 [Online]. Available at: https://www.iea.org/geco/ 
IEA/ OECD/ World Bank (2010). The Scope of Fossil-Fuel Subsidies in 2009 and a Roadmap for Phasing Out Fossil Fuel Subsidies. International Energy Agency (IEA), Organisation for Economic Co-Operation and Development (OECD), and The World Bank, Paris, France and Washington, DC, USA. Available at: www.iea.org/weo/docs/second_joint_report.pdf.

Johnston P, Vos J (2005) Pacific regional energy assessment 2004: a regional overview report. Apia, Samoa: Secretariat of the Pacific Regional Environmental Programme (SPREP).

Kaufmann RK (2004). The mechanisms for autonomous energy efficiency increases: A cointegration analysis of the US energy/GDP ratio. Energy Journal, 25(1), pp. 63-86.

Kruyt, B, van Vuuren DP, de Vries HJM, and Groenenberg H (2009). Indicators for energy security. Energy Policy, 37(6), pp. 2166-2181.

Lau KM, Kim KM, Sud YC, Walker GL (2010) Response of the water cycle of West Africa and Atlantic to Radiative Forcing by Saharan Dust. In AGU Fall Meeting Abstracts.

Martinot E (1998). Energy efficiency and renewable energy in Russia: Transaction barriers, market intermediation, and capacity building. Energy Policy, 26(11), 905-915.

Midilli A, Dincer I, Ay M (2006). Green energy strategies for sustainable development. Energy Policy, 34(18), pp.3623-3633.

Midilli A, Dincer I, Rosen MA (2004a) On hydrogen energy strategies. In: Proceedings of Hydrogen and Fuel Cells Conference and Trade Show, September 25-28, http://www.hydrogenfuelcells2004. com/ Toronto, Canada.

Midilli A, Dincer I, Rosen MA (2004b) On hydrogen energy strategies and global stability and unrest. In: Proceedings of Hydrogen and Fuel Cells Conference and Trade Show, September 25-28, http://www.hydrogenfuelcells2004.com/, Toronto, Canada.

Mundaca L, Neij L, Markandya A, Hennicke P, Yan J (2016). Towards a Green Energy Economy? Assessing policy choices, strategies and transitional pathways.

Munro, David (1995) “Sustainability: Rhetoric or Reality?” In A Sustainable World, edited by Thaddeus C. Trzyna, with the assistance of Julia K. Osborn. California: International Center for the Environment and Public Policy.

Roberts D (2017). There's a huge gap between the Paris climate change goals and reality. Current pledges are about a third of what's needed. https://www.vox.com/energy-andenvironment/2017/10/31/16579844/climate-gap-unep-2017.

Sathaye J, Lucon O, Rahman A, Christensen J, Denton F, Fujino J, Heath G, Mirza M, Rudnick H, Schlaepfer A, Shmakin A ( 2011). IPCC Special Report on Renewable Energy Sources and Climate Change Mitigation, eds Edenhofer O, et al. (Cambridge Univ Press, Cambridge, UK).

Schurr SH (1984) Energy use, technological change, and productive efficiency - an economic historical interpretation. Annual Review of Energy, 9, pp. 409-425.

Sen S, Ganguly S (2017). Opportunities, barriers and issues with renewable energy development-A discussion. Renewable and Sustainable Energy Reviews, 69, 11701181.

Sovacool BK (2009) The cultural barriers to renewable energy and energy efficiency in the United States. Technology in Society, 31(4), pp. 365-373.

Stern DI (2011) The role of energy in economic growth. Ecological Economics Reviews, 1219, pp. 26-51.

The Climate Group (2009). China's Clean Revolution II: Opportunities for a Low-carbon Future, Beijing: True North.

The report of the WCED: Our Common Future: Report of the World Commission on Environment and Development UN Doc GA/42/427 (1987) (hereafter WCED Our Common Future). 
UNDP (2010) Human Development Report 2010. United Nations Development Programme (UNDP), New York, NY, USA.

UNDP/WHO (2009) The Energy Access Situation in Developing Countries: A Review Focusing on the Least Developed Countries and sub-Saharan Africa. United Nations Development Programme. New York, NY, USA.

UNEP (2010). Global Trends in Sustainable Energy Investment 2010. Analysis of Trends and Issues in the Financing of Renewable Energy and Energy Efficiency. United Nations Environment Programme (UNEP) and Bloomberg New Energy Finance, Nairobi, Kenya UNEP, BNEF, FS (2015). Global trends in renewable energy investment; UNEP Collaborating Centre, Frankfurt School of Finance and Management, Germany.

UNFCCC (United Nations Framework Convention on Climate Change). Report on the Conference of the Parties on its sixteenth session, held in Cancun from 29 November to 10 December 2010, FCCC/CP/2010/7/ Add.1, United Nations.

Vos RO (2007) Defining sustainability: a conceptual orientation. Journal of Chemical Technology and Biotechnology, 82(4), pp. 334-339.

Wen-Cheng Lu (2017) Greenhouse Gas Emissions, Energy Consumption and Economic Growth: A Panel Cointegration Analysis for 16 Asian Countries. International Journal of Environmental Research and Public Health.

West J, Bailey I, and Winter M (2010) Renewable energy policy and public perceptions of renewable energy: A cultural theory approach. Energy Policy, 38(10), pp. 5739-5748.

World Bank (2010). World Development Indicators 2010. World Bank, Washington, DC, USA, $489 \mathrm{pp}$

Yushchenko A,Patel MK (2016). Contributing to a green energy economy? A macroeconomic analysis of an energy efficiency program operated by a Swiss utility. Applied energy, $179,1304-1320$. 